\title{
Focusing Project Financing for Growth and Realizing the Higher Objectives of Sharī'ah
}

\section{Muhammad Ayub *}

The Editor, Journal of Islamic Business and Management

\section{Keywords}

Islamic Banks and

Finance Institutions,

VBI,

ESG,

Sustainable Development Goals (SDGs), Project Financing

\begin{abstract}
Islamic system of finance has the capacity to serve the purpose of financial intermediation as a means to create sustainable value in the real economy at national and global levels. However, the most of Islamic Banks and Financial Institutions (IBFIs) are lacking in application of the Divine principles in letter and spirit. They have not learned the lesson of avoiding finance products that led to instability, injustice and crises in the global finance. They might be lagging behind the conventional institutions in adoption of value based finance that emerged in global finance in the wake of GFC, 2008 (World Bank and Islamic Development Bank Group, 2016; p. 6) to focus on Value Based Intermediation (VBI), Environment, Social and Governance (ESG) aspects and the stakeholders approach. This article focuses on the area of project financing by the IBFIs for different sectors including communication means, energy, residential and commercial buildings, infrastructure and socio-economic projects, and the role that Islamic banks can play in financing the projects leading to development and shared prosperity. Its finding is that while the conventional institutions are turning to the ethics and values based financial intermediation and business, it's more a duty of the IBFIs to move to VBI by focusing on project financing.
\end{abstract}

KAUJIE Classification: E2, H13, H46, H54, I23, K13, L2, L33

JEL Classification: G2, L31, M14, O44, Q56

(C) 2019 JIBM. All rights reserved.

\section{INTRODUCTION}

Islamic economics and finance has capacity to play crucial role in alleviating extreme poverty, an evil in any society, be it in advanced, underdeveloped or developing economy. Islamic finance is a part of Islamic economy to finance economic activities for promoting well-being of all creatures, including human well-being through social justice (Asutay, 2007, p. 172). It results in economic transactions that are transparent and just for all stakeholders through trade based finance, leasing, partnership, asset-backed $S u k \bar{u} k$, equity take-ups and fund

\footnotetext{
*Corresponding Author: Muhammad Ayub

${ }^{\dagger}$ Email: muhammad.ayub@ riphah.edu.pk
} 
management. As such, it has capacity to contribute for growth and shared prosperity. Al Rahahleh, Bhatti, and Misman (2019) have provided a brief history of evolution of Islamic finance from Prophetic era to the modern-day Islamic Banking and Finance (IBF) [1962 to 2016]. They reviewed the main characteristics of Islamic banks in comparison with the main characteristics of conventional banks.

The paradigm behind Islamic finance and its principles is to create a stakeholders-focused and socially responsible financial system. "Sharī'ah-compliant transactions must be backed by tangible and identifiable assets that anchor the financial sector in the real economy" (Damak, 2019). Assets to be financed need screening based on Divine principles including social, environmental, moral or ethical criteria. It requires that investment is based on social impact, and the value-based factors are integrated in all banking, finance and investment activities. There is a consensus that the objective of economic development has to be the shared prosperity of all segments of a society through equitable distribution of wealth, and not merely the growth (World Bank and Islamic Development Bank Group, 2016).

However, IBFIs do not seem to be moving to maturity aligned to achieving their objectives despite their functioning over last 45 years since 1975. They adopted generally the legal stratagems to 'Islamize' the conventional products and services using technicalities of jurisprudence (El-Gamal, 2005). By the time, IBFIs replicate any conventional products, the conventional finance moves much ahead. The 'financialisation' that started since 1970s/1980s led to crises in global economy and finance. As such, the moves for 'Responsible Banking', 'Green Banking', VBI, ESG factors and the UN-supported "Principles for Responsible Investment" are being increasingly embedded in the culture of global banking and finance. But, the IBFIs are generally locked-up in ensuring legal Sharī'ah compliance to replicate the conventional products without taking care for the substance. Reliance only on fiqh technicalities to replicate the conventional products with the sole objective of maximizing financial returns has led to serious concerns about their credibility as Islamic institutions.

The article in hand is to make a case for the IBFIs to reconsider their policies and operations to incorporate the principles of Islamic moral economy and finance. To be more specific, we suggest the focus on 'Project Financing' by the IBFIs that could help them in adoption of the principles of Islamic finance in true spirit by strengthening the linkage between finance and the real economy. Supported with regulatory steps, it could also result in application of the VBI and ESG related factors in line with the global move aiming at shared growth and realizing the SDGs.

\section{ISLAMIC FINANCE: DIRECTION AND PRACTICES}

Islamic finance has developed exponentially in all areas of financial institutions, instruments, markets and the assets with presence in 131 countries. The total Islamic finance assets that were \$2.4 trillion in 2017, increased to $\$ 2.5$ trillion in 2018 showing an increase of 3 percent. Growth in Islamic banking, the biggest sector of Islamic finance, slowed to 2 percent in 2018 with its total assets of $\$ 1.76$ trillion. Despite the slowdown for some years, Islamic finance has been increasingly noticeable in global finance spreading across all areas around the world (ICD-Rifinitiv, 2019). 
The global issuance of $S u k \bar{u} k$ since beginning surpassed US\$ 1 trillion in 2018. The Refinitiv's Islamic Finance Development Indicator (Refinitiv, 2019) Report has prepared an annual score for the overall health of the industry across five areas namely Quantitative Development, Knowledge, Governance, Corporate Social Responsibility (CSR), and Awareness for 131 countries. Islamic FinTech (Financial technology) is also changing the dynamics of the industry (Standing Committee for Economic and Commercial Cooperation of the OIC, 2018). Recently, the block chain-based micro $S u k u \bar{k}$ have been issued in Indonesia (International Islamic Finance Market, 2019), while Islamic FinTechs played a role in promoting the industry in the UK and the US during 2018 (ICD-Rifinitiv, 2019).

Four main areas are important in terms of incoming literature on Islamic finance. These are: i) Prime markets for Islamic finance; ii) Regulation and governance in Islamic finance; iii) the nature of contracts and instruments for funding and investment and their markets; and iv) the impact of Islamic financial services being provided in terms of maqāssid al-Sharī'ah and the objective of Islamic finance.

The rapid growth of Islamic banking drew interest from conventional banks, many of which also started Islamic banking over the years (Syakhroza, Paolella, \& Munir, 2019). It created competitive as also complementary relationship between the full-fledged Islamic banks and the conventional banks offering Islamic banking or non-banking financial services. One result of this phenomenon is that in case any Sharī'ah committee of any of the latter category of banks, with any of the renowned scholars as a Shari' 'ah committee member, approves any structured product, the Shari 'ah committees of other banks have to approve that product under market pressure. It becomes the move for "Islamizing" any conventional products without any limitation-treasury bills, commercial paper, derivatives, shares of conventional banks, etc. IBFIs, particularly the Islamic Funds, had shown more resilience than conventional finance to the recent Global Financial Crisis (Mansor, Al Rahahleh, \& Bhatti, 2019), but that could be because of the reason that their involvement in financial derivatives and other structured products was minimal by that time.

Islamic finance markets in Malaysia, Pakistan, UAE and Bahrain are important in terms of the range of different categories of products. But, the most of the commonly used products in all these markets are subject to severe criticism with regard to the Shari' ${ }^{\circ}$ ah compliance. Sale of debts, organized tawarruq, short selling and other controversial products are being used in Malaysia. Organized tawarruq that was very rarely used by Islamic banks in Pakistan before 2010 has now become an excessively used product for clean and collateralized lending to the conventional banks that are doing arbitrage by investing in high yield Government securities. Other grey area products currently used in Pakistan are Running Mushārakah, Currency Salam and Bay' al-Mu'ajjal of near to maturity Ijärah Șukük that practically is the sale of receivables. Tawarruq, also called reverse murābahah or interbank murābaḥh financing, has become a major mode of deposits mobilization by banks in countries like UAE, Bahrain and Saudi Arabia (TR, 2017-18). 'Islamic lottery schemes' are being offered in Bahrain and some other Middle East markets to give prizes to the investors/investment account holders of 
Islamic banks [UAE National Bonds-Sukuk al-Wataniya, are one example of such schemes ${ }^{1}$ ]. Some efforts have been made by the regulators to introduce reforms. For example, the Bank Negara Malaysia (2019) and the State Bank of Pakistan (SBP) introduced a number of steps and measures through 'Islamic Financial Services Act, 2013' and the SGF, 2015 (for IBIs in Pakistan), respectively. But, practically a little improvement has been witnessed in terms of the level of Sharī'ah compliance in substance. In Pakistan, excessive use of 'Running Mushärakah' as replica of 'Running Finance' is the most serious example, besides increasing use of organized tawarruq, which blurred further the level of Shari' ${ }^{-}$ah compliance in the country (Ayub, 2019).

In Malaysia, DM/MM based house financing was introduced in 2007 as a better substitute for Bay' Bi-thaman Ajil (BBA). In 2013, nine banks were offering DM Home Financing. Although, issues have been raised about DM regarding fixing the rentals not based on market rates, and the purchase undertaking by the customer at the original prices instead of the market value, yet the DM is a good product that "looks like a perfect mode of finance literally; although in practice, it is far from being perfect. But the practical problems faced by MM are man-made and caused by the current policies and regulations that can be amended or replaced." Even then, the use of DM decreased in the later period with only five banks offering such house financing. Some banks have shifted their focus from MM to Commodity Murābaḥah after phasing out BBA (Zaaba \& Hassan, 2019).

The result is ever-increasing debt and inequality both at national and global levels, and the persistent threat of instability. Rajan (2011) in his influential book, Fault Lines (Ch: 1) argued that rising income inequality in the United States was one of the main reasons behind the 2007-08 global financial crisis. Rajan (2011) argued that the declining share of low-income households was compensated by ever-expanding credit facilities, which in turn increased fragilities in the economic system through high leverage ratios, creating systemic risk. Islamic banks are tending to adopt all such conventional products that culminate into ever-expanding credit facilities.

The result of emphasizing the form and neglecting the substance is that the Islamic banking industry is increasingly regressing in terms of responsible product development, values based investments and realization of objectives of socio-economic justice. A global approach with a different mindset is required for resolving the Shari' 'ah governance issues by adopting the AAOIFI and Islamic Financial Services Board (IFSB) standards (World Bank and Islamic Development Bank Group, 2016). AAOIFI's Governance Standard No. 7 on CSR, Conduct and Disclosure for IFIs is crucial in this regard.

\section{IBFIs Lagging Behind the Global Finance with Regard to CSR and VBI based Prac- tices}

The conventional finance institutions are moving to the ethical, responsible, social and VBI. A major milestone for the banking sector was reached in 2018 when the UN Environment

\footnotetext{
${ }^{1}$ An investor in such $s u k \bar{u} k$ says, upon winning a prize, "I topped my account in December, 2017 and won the one million AED in January, I did not imagine winning this amount of money. I plan to invest the money back into Dubai and in to my pet store ...(https://bit.ly/38i1Zrs)
} 
Program Finance Initiative (UNEPFI) established the Principles for Responsible Banking, with 28 banks from around the world committing to aligning their business strategies with society's goals. These 28 have now been joined by 17 more, highlighting the fast-growing trend of responsible finance around the world.

While the above-mentioned UN-supported document is being increasingly embedded in the culture of banking, Islamic banks which claim to be linking finance with the real economy, have not progressed so far in this direction. Of course, the BNM is the only exception that issued on November 01, 2019 the "Value-based Intermediation Financing and Investment Impact Assessment Framework (VBIAF)". According to the VBIAF, the adoption of VBI strategy is on a voluntary basis (Bank Negara Malaysia, 2019).

\section{THE POSSIBLE WAY FORWARD}

One possible way forward to get the benefits of Islamic finance for shared growth and sustainable development is to adopt the Islamic finance principles by focusing on Project financing while ensuring Sharí ${ }^{-}$ah compliance in substance. It is particularly for Islamic countries that are underdeveloped despite having the rich natural resources given by the nature. Pakistan is one such economy and we will discuss the potential of projects financing in realizing the dual goal of ensuring Shari' 'ah compliance and sustainable growth. But, first about the present state of economy of Pakistan!

Pakistan is a land of opportunities; unfortunately, however, nation didn't tap sincerely and efficiently. Pakistan's economy is entangled in debt trap, both domestic and foreign, to service which almost $50 \%$ of the Federal annual budget is consumed. The public debt reached 76.6 percent of GDP at end of FY 2018-19. The debt incurred by Public Sector Enterprises (PSEs) is separate that also continues to move along an upward trajectory. The more serious issue is that the borrowing rate from the banking system, private sector to the extent of 85 per cent, has increased by almost 100 per cent over the last 2 years (from around $7 \%$ to $14 \%$ p.a. payable on the T. Bills). The policy rate of the SBP has been raised to $13.25 \%$ unnecessarily that has hurt not only the poor and the business community, but also the State of Pakistan.

Due to excessive increase in the central bank's base rate and the KIBOR, banks financing to the private sector and the PSEs has reduced. Banks are interested mainly in high yielding risk free lending to the government. As per mid-term baking sector review for CY 2019, banks may continue to remain risk-averse in their lending behaviour due mainly to a pick-up in NPLs and weakening repayment capacity of firms (State Bank of Pakistan, 2019).

The government has increased its reliance on commercial banks for financing needs. The result is that the economy is in the grip of serious stagflation, while the earnings of banking sector have increased enormously due to higher interest rates on banks' investment in government securities. According to the noted economist, Dr. Kaiser Bengali (2019), "It looks like the budget (2019-20) has been designed to increase loans"

According to the United Nations Development Program (UNDP)'s Global Human Development Report (2019), 51.7pc of Pakistan's population suffers from intense deprivation. It requires policies that could lead to inclusive economic growth, favour the poor and target the 
increasing social and economic disparities. That is not possible without a structural change and improvement in the governance system.

A strong commitment of the State, the central bank and the fiscal authorities as well as a proactive regulatory framework is required to reverse the worsening trends in the economy and the society. As here we are concerned with Islamic banks, all such financing by them that is not associated with real production, business and economic activities has to be avoided. Focusing on project financing could be one possible way forward not only to avoid the increasingly worsening debt trap, but also to move to shared and sustainable growth.

\section{Exploring Project Financing as an Effective means to Growth and Development}

In project financing, financier mainly looks to the assets and revenue of the project in order to get return on investment. The focus in project financing is made on the allocation, management and analysis of the risks associated with the project, since the claim is now on the project, and not on the client.

According to Tariq Hameed of Norton Rose's Islamic finance team, project financing would generally involve pipelines, refineries, electric generation facilities and hydropower projects. Sharī'ah based project financing can be provided based on mushārakah/mudārabah, istisnnā and salam, ijärah and ijärah mawsüfah fi al-dhimmah (that involves the bank's construction and ownership of the project, with a subsequent lease to the project company concerned).

A landmark Islamic project finance deal regarding the Jordan's Queen Alia International Airport involved dual tranche conventional and Islamic lease facilities for the renovation, extension and operation of the airport. The approach was to enter into a 25-year head lease between the project company, the IDB and the Jordanian Government. After the head lease, the IDB and the project company entered into a sublease to lease the IDB's interest in the head lease for 18 years. As allowed in the Shari' ah principles, the rentals were flexible enough to accommodate any delay in the project's construction (Mokhtar, 2008).

State Bank of Pakistan (2014) has identified the modes and possible challenges in Islamic project finance. The issue is that banks in private sector are least eager to go to villages, smaller towns and the less developed areas where the most of the unbanked population lives. Despite sustained efforts by the SBP since 2001, the level of financial inclusion is still very low. "In 2017, just 14\% of Pakistani adults had an account with a formal financial institution, quite below both the South Asian average of $33 \%$ and the average for all lower-middle-income countries of 41.4\%" (ZTBL, 2018).

The State Bank of Pakistan (2014) has indicated the following types/products for project financing by Islamic finance institutions: 
TABLE 1

Islamic Project Financing Types

\begin{tabular}{|c|c|}
\hline Categories & Way of Financing \\
\hline Asset based & $\begin{array}{l}\text { Ijārah (on existing/future assets i.e., forward lease), Ijārah in tranches, } \\
\text { Diminishing Mushārakah }\end{array}$ \\
\hline Debt Based & Istiṣnā' (manufacturing/commissioning), murābaḥah (cost plus profit) \\
\hline Equity Based & Muḍ̄ärabah, Mushārakah \\
\hline Agency Based & Wakālah \\
\hline Combination & Istiṣnā' cum Ijārah, wakālah cum Ijārah etc. \\
\hline
\end{tabular}

\section{Brief Discussion on the possible Modes/Products}

Mushārakah cum ijārah product: IBFIs could join hand with professional construction, engineering and manufacturing companies on mushārakah basis to produce such assets, energy producing units etc. that could be leased for medium and long terms. Upon completion of the assets, the same could be leased against rentals payable to the partners based on their shares.

Partnership: It can be a project-specific partnership of short duration in which the assets and properties acquired would be held as community property until the end of the life of the partnership. The bank would be acting as one of the co-financiers and not distinct from other financiers. It could also be a long term venture in which the bank might provide a portion of the equity of a newly established firm or buy into an existing corporation. The regulator(s) may determine the maximum amount of equity participation by the banks and the minimum amount of participation by other partners in the ventures. The banks could be allowed to sell their shares whenever they deem it appropriate.

Mushärakah cum installments sales product: It could be partnership of short and medium term duration in commercial, production, and service activities. The banks' share in the partnership could be sold to the entrepreneur partner on installments basis with profit margin for the financing partner(s).

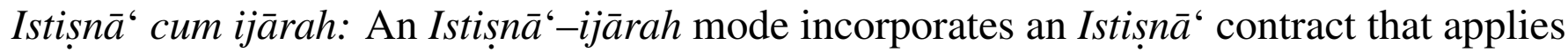
to the construction phase of a project, and an ijārah contract for the operations phase. The Istisnna $\bar{a}^{6}$-ijārah structure is commonly used because the Istișn $\bar{a}^{6}$ matches the requirements of a procurement agreement, while the ijärah provides the mechanism for the repayment of the facility. The construction of Queen Alia International Airport is one such example of project financing.

Wakālah cum ijārah contract: The client is employed as bank's agent in accordance with the terms of an agency agreement for project financing. The client, as the agent, would procure the design, engineering, construction, testing, commissioning and delivery of the assets identified in the Wakālah agreement for the financier who would bear the risk of all the above mentioned activities. After completion, the project would be leased to the client. 
Salam based financing: Salam sale is intended to help farmers, Small and Medium Enterprises (SMEs) and rural women in handicraft businesses earn money to enable them to create demand for their products that may also lead to the development of a proper line of production. In addition to financing the farmers for their production activities, salam and

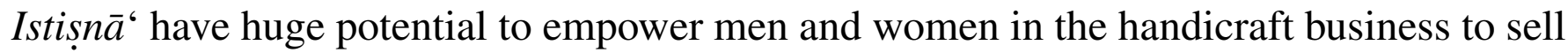
their innovative products via the Internet through business partners who are trustworthy and wish to create wealth not only for themselves but also for the underprivileged men and women in the handicraft business. Salam and Istisna $\bar{a}^{6}$ based finance may enable the poor to become successful entrepreneur and financially independent in a few years, provided the system is implemented and managed with care and commitment.

For supply of sufficient funds for the projects, all non-banked financial institutions may be enabled to provide banking facilities to get funds from the public and finance the specific projects. They will be serving as open-ended mutual funds and funded by the general investors from the public. They may particularly finance the socio-economic projects at micro and local levels. It would lead to an unprecedented model of financial inclusion and hence increase the growth in the economy. Islamic financial institutions would be getting funds from term deposits as also from the capital market by selling medium and long-term investment certificates and $s u k \bar{u} k$. The entrepreneurs may get project financing either directly from the financier or by issuing any Sharī'ah compliant certificates or șukük.

\section{Islamic Fund Management and Projects Financing}

Islamic fund management plays a significant role for mobilising savings to promote economic growth, while ensuring Sharī'ah compliance (Al Rahahleh \& Bhatti, 2017). Islamic funds address a number of issues faced by an individual investor seeking Sharī'ah-compliant investment avenues, including selecting Sharī'ah-compliant investments with lowest cost, analyzing financial ratios of investee companies, and Shari' ${ }^{`}$ ah governance in the form of investment reviews and audits.

Islamic funds industry expanded from about 800 Islamic funds in 2008 to 1,161 as at end2017, accounting for some USD 66.7 billion of assets as on that date (Standing Committee for Economic and Commercial Cooperation of the OIC, 2018). Of course, Islamic funds industry is concentrated, so far, in a few jurisdictions. It implies that a large potential exists in other Islamic finance markets. The Funds market in Pakistan has been among the top return rate earners in the Emerging Markets Funds. A key measure of success for any Islamic fund market is the extent to which it unlocks and promotes opportunities for savings mobilization and projects based capital formation.

Different types of funds offer investors an easy and low-cost opportunity to invest in a diversified pool of investment with specified investment objectives (Standing Committee for Economic and Commercial Cooperation of the OIC, 2018). The main requirement for Islamic funds is Sharī'ah compliance. Keeping in view the tolerance level in various markets, fund managers and the investors have been allowed to invest in companies that might be involved in interest based or other harām businesses to some extent. The prohibited businesses and 
operations of such companies are restricted to a certain tolerable limit for which certain ratios have been suggested by the Sharí 'ah boards (Accounting and Auditing Organization for Islamic Financial Institutions, 2015; Standing Committee for Economic and Commercial Cooperation of the OIC, 2018).

Types of funds with regard to the investment portfolios and the managers that best suit projects financing are private and corporate equity funds, wealth funds, commodity funds, Venture Capital funds, pension funds, index fund, fund of funds, Real Estate Investment Trust (REITs) and other funds suiting various investors based on their risk and profit payments requirements. Waqf can be used to strengthen business support to the institutions to lower the cost for supply of goods and services to the poor and to support and build infrastructure institutions.

Waqf Funds, Zakāh and 'Ushr Funds and Hajj Funds could also play crucial role in providing finance for various social, economic and religious activities. Such funds would invest in various socio-economic projects like energy supply in a locality, training centers, agro-based small and medium level units, and any diversified pool of properties. The 'Fund of Islamic Funds' would serve as a multi-manager and might be operated jointly by the regulator's representatives and the private sector investors to help any Fund at the time of dire need for liquidity. In many cases the properties of $a w q \bar{a} f$ can be securitized through the issuance of $s u k \bar{u} k$ on the usufruct of waqf properties. The proceeds could be used to expand operations and build new social projects.

Islamic funds would invest only in Sharī'ah-compliant stocks, portfolios or projects, based on the approved Sharī'ah screening process and compliance criteria. In this regard, the Guiding Principles on Governance for Islamic Collective Investment Schemes (ICIS) issued by the IFSB (IFSB-6) have to be implemented. These principles pertain to compliance with the Shari' 'ah norms, governance of Islamic funds, transparency and disclosure made in in an investor-friendly manner; creation of reserves and the smoothing of any dividend payments, and general protection for ICIS investors.

\section{Sִukūk as a Tool of Funding for Projects Financing}

$S u k \bar{u} k$ are among the best means of financing large production, business and infrastructure projects that are beyond the ability of a single party to finance. It is an ideal mean for investors to deploy large or small capital and a good way of managing liquidity for the IBFIs. By way of investing in $s u k \bar{u} k$, the IFIs could finance the projects in real estate, investment trusts, the halāl food industry, trade financing instruments, and infrastructure projects. Șukūk can be issued to mobilize funds for establishing new projects, any existing project, or financing any business activity relating to any project (Elian, 2015).

The Malaysian Securities Commission's (SC) announced in 2014 the SRI Șukūk Framework to finance Shari' 'ah compliant green, social and sustainable projects. The latest development in this regard is issuance of Green \& SRI Șukūk to support financing to SME. Șukūk issuance via Blockchain is also a welcome innovation.

It is pertinent to observe that despite the global slowdown, suku $\bar{u} k$ have continued strong growth, with a rise of 10 percent to $\$ 470$ billion in 2018. "The funding need for social uplift 
and sustainability themed projects in general in the OIC countries is sizable, paving the way for green and socially responsible Suku $\bar{u}$. It is estimated that the funding so required by 2040 is USD 7.2tr with an expected shortfall of USD 1.6tr in 13 OIC countries. This funding gap can ideally be closed through SRI Investing" (International Islamic Finance Market, 2019).

In Malaysia, the issuance of Green SRI Suk $u k$ has gone up to US\$ $924 \mathrm{~m}$ mostly for funding solar power projects and, to some extent, for urban real estate Development. Similarly, Indonesia has been planning to issue sovereign green $s u k \bar{u} k$ of US\$ 1.25 billion for a number of projects.

The Blockchain has emerged as an effective tool of communication between investors and the fund users. It is an operational medium through which the latter can notify investors of event occurrences, request their consent, or ask for advice regarding instructions and corrective actions in a timely manner. It could also assists in transacting (selling and settling) the $s u k \bar{u} k$ in the secondary market.

\section{Financing the Infrastructure Projects}

$S u k \bar{u} k$ can be issued to fund small, medium and long-term infrastructure projects as has been done in recent years in Saudi Arabia, Qatar, UAE, Malaysia and Indonesia. Qatar announced $\$ 65$ billion of investments in infrastructure projects ahead of the World Cup in 2022. The former British Prime Minister, David Cameron, also indicated the importance of $s u k \bar{u} k$ for financing infrastructure projects (Elian, 2015).

All economies, particularly the Islamic countries may get funding through $s u k \bar{u} k$ issuance for projects including, inter alia, seaports, airports, electricity generation and means of communication. S Sukūk issued by the Government and the private sector entrepreneurs would help the Government and the entrepreneurs raise money for infrastructure and other socioeconomic projects.

\section{VBI, SRI and the Project Financing}

The Bank Negara Malaysia (2019) issued, after due consultation process, a guidance document, "Value-based Intermediation Financing and Investment Impact Assessment Framework (VBIAF)" in November 2019 to promote VBI in Malaysia. It is a "key development in the right direction to shape the future of IBFIs in a more humane sense by considering the interests of other stakeholders beyond capital" (Mergaliyev, Asutay, Avdukic, \& Karbhari, 2019). Further, the social impact financing in the areas of education, healthcare, and housing has been in focus since 2010 in a number of countries.

The area of Sustainable and Responsible Investment (SRI) has remarkable implications for Islamic asset management industry to increase its contribution to shared prosperity in societies. Emphasis on application of values related to social and environmental aspects is inherent in Islamic theology and jurisprudence, which has important implications for the investment behavior of Islamic investors (World Bank and Islamic Development Bank Group, 2016).

Projects based Islamic micro financing with waqf and charity funds and investments by the affluent in the society could be helpful in building a caring society to live in peace and shared 
prosperity. It is through mutual help, cooperation, sharing of wealth with the poor, zakāh, waqf and charity, close monitoring and follow-up, that poverty can be eliminated in order to achieve a just society that makes the Islamic system unique and universal. Humanitarian impact $s u k \bar{u} k$ and certificates can be issued in almost all Islamic countries by waqf and other non-profit institutions and philanthropists for social welfare projects. Islamic banks need to involve donor and waqf institutions.

Establishing Islamic Microfinance Project Enterprises (IMFPE) could be a powerful tool for reaching out to the poor, creating jobs and alleviating poverty. Small scale projects need to be financed for handicrafts that involve innovation and creativity. The gift business and handicraft are increasingly getting importance all over the world (Al-Harran, 2008).

To conclude, keeping in view the divergence between the aspired objective and the current practices of the IBFIs, researchers are increasingly suggesting the Islamic moral economy augmented maqāṣid al-Sharī' ah and CSR based financial services (Zadek, Evans, \& Pruzan, 2013). Well thought-out reforms are needed in the Sharī'ah governance mechanism and processes. These reforms have to be in holistic perspective guided by maqāssid, as indicated by the jurists. Islamic international institutions and the Standards setting bodies have to take the lead in collaboration with the regulators at national levels. Focus is also needed on knowledge, education, capacity building, and strengthening the Sharī ${ }^{`}$ ah advisory services.

Offering project finance that is not only consistent with Shari' ah principles, but is also attractive to financiers, is the biggest challenge. Catering to the risks associated with project finance is crucial which requires a lot of time and efforts to design the products and their documentations/processes to mitigate the possible legal, market and other risks and ensuring Shari'ah compliance.

The IBFIs need to explore the sukūk market for medium and long term funding of the projects. Formal SMEs contribute up to $60 \%$ of total employment and up to $40 \%$ of GDP in emerging economies. These numbers are significantly higher when informal SMEs are included (International Islamic Finance Market, 2019). The regulators need to come up with innovative concepts and an integrated scheme for obliging the IBFIs to finance short, medium and long-term projects to empower the rural community and the entrepreneurs at small and medium levels. Focusing on project financing and ethical ventures would go a long way in creating employment opportunities for the youth and fresh graduates who are seeking new business, and for achieving social justice.

The conventional financial institutions are moving to the ethics and values based business in the backdrop of the global crises 2007-8. The "Global Alliance for Banking on Values" [GABV] has suggested the principles of value-based banking including serving the real economy, long-term relationships with clients, resilience to outside disruptions, and transparent and inclusive governance. All these are the objectives of Islamic finance as well. Therefore, the IBFIs must turn to the CSR, ESG and the VBI based activities. Moving to project financing could be one way to realize the objective. Of course, it needs coming out of straight jacket of innovations for replicating conventional products for financial gains. 


\section{REFERENCES}

Accounting and Auditing Organization for Islamic Financial Institutions. (2015). Sharī‘ah standards. Retrieved from https://bit.ly/2OMXq0K

Al Rahahleh, N., Bhatti, M. I. \& Misman, F. (2019). Developments in risk management in Islamic finance: A review. Journal of Risk and Financial Management, 12(1), 1-22. doi: https://doi.org/10.3390/jrfm12010037

Al Rahahleh, N., \& Bhatti, I. (2017). Mutual fund performance in Saudi Arabia: Do locally focused equity mutual funds outperform the Saudi Market? (Unpublished thesis). Faculty of Economics and Administration, King Abdulaziz University, Jeddah; Saudi Arabia.

Al-Harran, S. (2008). Islamic microfinance project enterprises: Managing the challenges. Islamic Finance News. Retrieved from https://bit.ly/3bv5k8p

Asutay, M. (2007). Conceptualisation of the Second best solution in overcoming the social failure of Islamic banking and finance: Examining the overpowering of homoislamicus by homoeconomicus. IIUM Journal of Economics and Management, 15(2), 167-195.

Ayub, M. (2019). Strengths, gaps and issues in Shari' ah governance framework 2015 for IBIs in Pakistan. In T. Azid, A. Alnodel, \& M. Qureshi, M. (Eds.) Research in corporate and Shar'`ah governance in the Muslim world: Theory and practice. London, UK: Emerald Publishing Limited. doi: https://doi.org/10.1108/978-1-78973-007-420191023

Bank Negara Malaysia. (2019). Value-based intermediation financing and investment impact assessment framework guidance document. Retrieved from https://bit.ly/39qSQwU

Bengali, K. (2019). Prepared by IMF, current budget designed to increase loans. Retrieved from https://bit.ly/37kqZ03

Damak, M. (2019). Islamic finance and ESG: The missing 's'. Retrieved from https://bit.ly/2Sjuv6j

El-Gamal, A. (2005). Limits and dangers of Sharī'ah arbitrage. In Nazim, S. (Ed.), Integrating Islamic finance into the mainstream: Regulation, standardization and transparency. Cambridge, MA: Harvard Law School.

Elian, M. (2015). Why the U.S. should accommodate $s u k \bar{u} k$ ? And how accommodating sukük will protect and benefit the American financial system? Minnesota Journal of International Law, 24, 1-38.

ICD-Rifinitiv. (2019). Islamic Finance development report, shifting dynamics. Retrieved from https://bit.ly/2w5ulqx

International Islamic Finance Market. (2019). Sukük report-A comprehensive study of the global sukük market. Retrieved from https://bit.ly/2OKUcuk

Mansor, F., Al Rahahleh, N., \& Bhatti, M. I. (2019). New evidence on fund performance in extreme events. International Journal of Managerial Finance, 15(4), 511-532. doi: https://doi.org/10.1108/ijmf-07-2018-0220

Mergaliyev, A., Asutay, M., Avdukic, A., \& Karbhari, Y. (2019). Higher ethical objective (Maqasid al-Shari' ah) augmented framework for Islamic banks: Assessing ethical performance and exploring its determinants. Journal of Business Ethics, (Accepted article). 1-38. doi: https://doi.org/10.1007/s10551-019-04331-4 
Mokhtar, S. (2008). Challenges in project finance. Retrieved from https://bit.ly/2UJsZfr

Rajan, R. G. (2011). Fault lines: How hidden fractures still threaten the world economy. Scottsdale, AR: Princeton University press.

REFINITIV. (2019). Islamic finance ESG outlook 2019: Shared values. Retrieved from https://refini.tv/2SCYZz9

Standing Committee for Economic and Commercial Cooperation of the OIC. (2018). Islamic fund management. Proceedings of the 11th Meeting of the COMCEC Financial Cooperation Working Group, Ankara, Turkey.

State Bank of Pakistan. (2014). Islamic infrastructure project financing in Pakistan - March. Karachi, Pakistan: State Bank of Pakistan.

State Bank of Pakistan. (2019). Mid-Year Performance Review (MPR) of the banking sector. Karachi, Pakistan: State Bank of Pakistan.

Syakhroza, M. A., Paolella, L., \& Munir, K. (2019). Holier than thou? Identity buffers and adoption of controversial practices in the Islamic banking category. Academy of Management Journal, 62(4), 1252-1277. doi: https://doi.org/10.5465/amj.2016.1017

United Nations Development Program. (2019). Global human development report: Beyond income, beyond averages, beyond today: Inequalities in human development in the 21st century. Retrieved from https://bit.ly/2SBnPzG

World Bank and Islamic Development Bank Group. (2016). Global Report on Islamic Finance: Islamic Finance: A Catalyst for Shared Prosperity. Washington, DC, WA: World Bank. doi: https://doi.org/10.1596/978-1-4648-0926-2

Zaaba, N. I. B. M. A., \& Hassan, R. (2019). Why Islamic banks are reluctant to offer Mushārakah mutanaqisah for home financing: The case of Maybank Islamic and Affin Islamic bank. Turkish Journal of Islamic Economics, 6(1), 51-66. doi: https://doi.org/10.26414/a044

Zadek, S., Evans, R., \& Pruzan, P. (2013). Building corporate accountability: Emerging practice in social and ethical accounting and auditing. London, UK: Routledge.

ZTBL, Pakistan (2018). Research study: Financial inclusion in Pakistan. Retrieved from https://bit.ly/37qofhK 